\section{NEW DISTRIBUTION RECORDS OF TORTOISES (CHELONIA: TESTUDINIDAE) FROM BARAK VALLEY, ASSAM, NORTHEASTERN INDIA WITH NOTES ON ECOLOGY AND VERNACULAR TRADITIONAL TAXONOMY}

\author{
Kulendra Chandra Das ${ }^{1} \&$ Abhik Gupta ${ }^{2}$ \\ ${ }^{1}$ Department of Environmental Science, PUC, Mizoram University, Aizawl, Mizoram 796001, India \\ ${ }^{2}$ Department of Ecology and Environmental Science, Assam University, Silchar, Assam 788011, India \\ ${ }^{1}$ drkulendra.das@gmail.com (corresponding author), 2abhik.eco@gmail.com
}

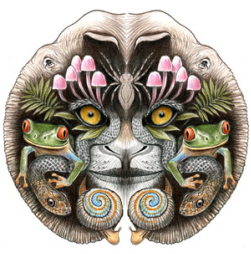

ISSN 0974-7907 (Online) ISSN 0974-7893 (Print)

OPEN ACCESS
Abstract: India is home to five species of tortoises of which the two endangered species are found in northeastern India. We report for first time new distributional records of Indotestudo elongata and additional site records of Manouria emys phayrei from 17 different locations in the Barak Valley region of Assam.

Keywords: Assam, Barak Valley, Chelonia, distributional record, land tortoise, northeastern India, Testudinidae.
Family Testudinidae includes 57 living species of tortoises in 16 extant genera in the world (Uetz \& Hosek 2014), all of which are largely terrestrial, and together represent about $18 \%$ of the extant world chelonian diversity (Ernst \& Barbour 1989).

Northeast India is known as a 'Turtle Hotspot' and habitat to 22 out of 30 species of freshwater turtles and tortoises found in India (Ahmed et al., 2009, Kundu et al. 2013a, b). Five species of land tortoises belonging to the family testudinidae are known to occur in India, viz., the Travancore Tortoise Indotestudo travancorica (formerly Geochelone travancorica) and Star Tortoise Geochelone elegans from the southwest; and Elongated Tortoise
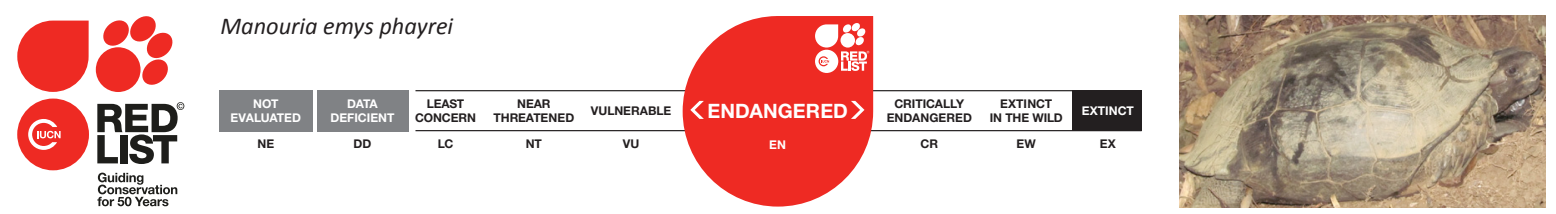

DOI: http://dx.doi.org/10.11609/JoTT.03623.7017-23

Editor: Raju Vyas, Vadodara, Gujarat, India

Date of publication: 26 March 2015 (online \& print)

Manuscript details: Ms \# 03623 | Received 10 May 2013 | Final received 06 March 2015 | Finally accepted 10 March 2015

Citation: Das, K.C. \& A. Gupta (2015). New distribution records of tortoises (Chelonia: Testudinidae) from Barak Valley, Assam, northeastern india with notes on ecology and vernacular traditional taxonomy. Journal of Threatened Taxa 7(3): 7017-7023; http://dx.doi.org/10.11609/JoTT.03623.7017-23

Copyright: @ Das \& Gupta 2015. Creative Commons Attribution 4.0 International License. JoTT allows unrestricted use of this article in any medium, reproduction and distribution by providing adequate credit to the authors and the source of publication.

Funding: The funding came from G.B. Pant Institute of Himalayan Environment and Development, Almora, Uttaranchar-F.No.GBPI/IERP/01-02/NE/10/596 dated 30 March, 2002, and University Grants Commission, New Delhi -No.F.16-110/2006 (SA-II) dated 16th March, 2007 providing financial support in the form of RGNF to K.C. Das

Competing Interest: The authors declare no competing interests.

Acknowledgements: Sincere thanks also go to the Department of Forest, Government of Assam, for their necessary support in this research. Special thanks are due to the hunters and informers for their generous help in the field study.
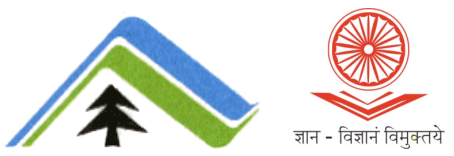
Indotestudo elongata (formerly Geochelone elongata), I. forstenii and Asian Brown Tortoise Manouria emys from the northeastern India (Das 1985, 1995a,b, 2002; Das \& Andrews 1997; Ahmed et al. 2009; Kundu et al. 2013a,b). Indotestudo travancorica, Nilssonia leithii and Vijayachelys silvatica are endemic to southern India. All these species are largely terrestrial, inhabiting forested areas. Very few intensive surveys of the tortoise fauna of northeastern India have been conducted in order to determine the full extent of distribution of different taxa. Again, within northeastern India, the chelonian fauna in general and testudines in particular of the Barak Valley region in southern Assam have remained poorly investigated barring a couple of publications (Das 2008; Das \& Gupta 2011). The present study, conducted during July 2002-June 2007, was with the objective of reporting the distribution of $I$. elongata and $M$. emys phayrei in Assam.

\section{Materials and Methods}

The survey was conducted from July 2002 to June 2007 , in the Barak Valley region of Assam $\left(24^{0} 12^{\prime}-25^{\circ} 8^{\prime} \mathrm{N}\right.$ \& $\left.92^{\circ} 12^{\prime}-93^{\circ} 15^{\prime} \mathrm{E}\right)$ that covers the three districts of Cachar, Hailakandi and Karimganj. Records of tortoises were made through direct sightings and by questioning the people in different areas, especially the fishermen and jhum cultivators who occasionally hunt turtles. Photography and morphometric measurements of live pet specimens were taken and carapaces and/or plastrons were collected from the villages near the study sites. Identification was made by means of standard keys (Smith 1931; Das 1991). As both the testudinide species reported here are endangered and protected, photographs of live specimens and some carapace samples are deposited in the Animal Biodiversity Museum of the Department of Ecology \& Environmental Science, Assam University, Silchar, India.

\section{Results and Discussion}

Indotestudo elongata (Image 1) (AU-Ecol/ABM/ Reptilia/Chelonia/ie-5a) and Manouria emys phayrei (Image 2) (AU-Ecol/ABM/Reptilia/Chelonia/me-8a) were recorded from 17 sites in the three Barak Valley districts of Cachar, Hailakandi and Karimganj in Assam (Fig. 1; Table 1).

\section{Manouria emys}

Manouria emys (Schlegel \& Muller, 1840) is protected under Schedule-IV of the Indian Wildlife (Protection) Act, 1972 and categorized as "Endangered"

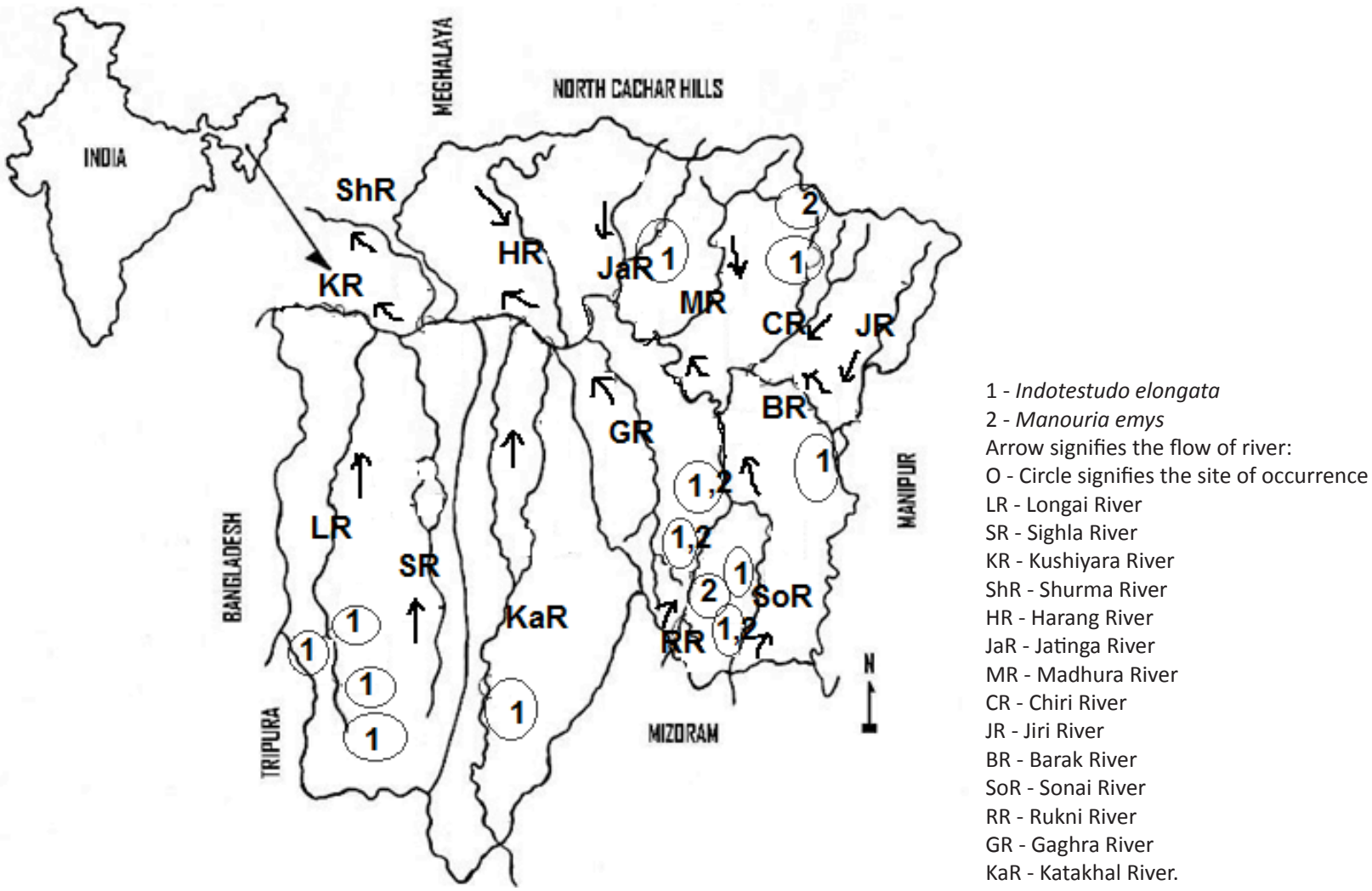

Figure 1. Map of Barak Valley shows sites of occurrence of terrestrial tortoises. 
Table1. Distributional records and vernacular names of Manouria emys phayrei and Indotestudo elongata from Barak Valley, Assam.

\begin{tabular}{|c|c|c|c|c|c|}
\hline $\begin{array}{l}\text { Name of species (range of size } \& \text { weight) } \\
\text { and vernacular name }\end{array}$ & Sites & District-wise name of sites & GPS location & Date of record & $\begin{array}{l}\text { No. of } \\
\text { record }\end{array}$ \\
\hline \multicolumn{2}{|c|}{ Manouria emys phayrei (size: $42-55 \mathrm{~cm}$; weight: $10.5-20.75 \mathrm{~kg}$ ) } & \multicolumn{4}{|c|}{ Cachar District (Town $24^{\circ} 49^{\prime} \mathrm{N}-92^{\circ} 47^{\prime} \mathrm{E}$ ) } \\
\hline \multirow{5}{*}{$\begin{array}{l}\text { Pahari kochchop (Hill Tortoise - Bengali*); } \\
\text { Mondur (Hill Tortoise - Chakma); Phrau } \\
\text { (Pnar); Yado (big tortoise, forest tortoise } \\
\text { - Dimasa); Telpui (Choroi and Mizo); Pepui } \\
\text { (Reang) }\end{array}$} & 1 & Jhagurapunji, forest village & $24^{\circ} 28^{\prime} \mathrm{N}-92^{\circ} 51^{\prime} \mathrm{E}$ & 09.ii.2004 & $1 \mathrm{~L}$ \\
\hline & 2 & Lailapur, hill forest & $24^{0} 31^{\prime} \mathrm{N}-92^{\circ} 46^{\prime} \mathrm{E}$ & 02.viii.2002 & $1 \mathrm{~L}$ \\
\hline & 3 & Baroalibeel, hill forest & $24^{0} 34^{\prime} \mathrm{N}-92^{\circ} 51^{\prime} \mathrm{E}$ & 03.viii.2002 & $1 \mathrm{C}$ \\
\hline & 4 & Baskandibazar, hill forest & $24^{\circ} 48^{\prime} \mathrm{N}-92^{\circ} 54^{\prime} \mathrm{E}$ & 06.i.2004 & $1 \mathrm{C}$ \\
\hline & 5 & Harinagar, hill forest & $24^{0} 55^{\prime} \mathrm{N}-93^{\circ} 06^{\prime} \mathrm{E}$ & 30.vi.2004 & $1 \mathrm{C}$ \\
\hline \multicolumn{2}{|c|}{ Indotestudo elongata (Size: $18-49 \mathrm{~cm}$; weight: $0.18-2.5 \mathrm{~kg}$ ) } & \multicolumn{4}{|l|}{ Cachar District } \\
\hline \multirow{14}{*}{$\begin{array}{l}\text { Bon kochchop (Forest Tortoise), Gecho } \\
\text { kochchop (Tree Tortoise), Pahari haldey } \\
\text { kochchop (Yellow Hill Tortoise), Shial } \\
\text { chekouria- Bengali*; } \\
\text { Suryamukhi (sunflower) Kacchuwa (Hindi); } \\
\text { Hunro (Pnar); Gonghang (Yellow Shell } \\
\text { Tortoise - Dimasa); Telrangchung (Yellow } \\
\text { Hill Tortoise - Choroi); Telang (Mizo); } \\
\text { Kerangkormo (Kerang=tortoise, Kormo= } \\
\text { Turmeric - Reang); Mon dur (Halam) }\end{array}$} & 1 & Jhagurapunji, forest village & $24^{\circ} 28^{\prime} \mathrm{N}-92^{\circ} 51^{\prime} \mathrm{E}$ & 09.ii.2004 & $1 \mathrm{C}$ \\
\hline & 2 & Bagiala, hill forest & $24^{0} 28^{\prime} \mathrm{N}-92^{\circ} 52^{\prime} \mathrm{E}$ & 01.viii.2002 & $1 C$ \\
\hline & 3 & Lailapur, hill forest & $24^{0} 31^{\prime} \mathrm{N}-92^{\circ} 46^{\prime} \mathrm{E}$ & 02.viii.2002 & $2 \mathrm{~L}$ \\
\hline & 4 & Dholai, reserve forest & $24^{0} 35^{\prime} \mathrm{N}-92^{\circ} 50^{\prime} \mathrm{E}$ & 22.vii.2003 & $1 C$ \\
\hline & 5 & Ganganagar, Bhuban hill forest & $24^{\circ} 45^{\prime} \mathrm{N}-93^{\circ} 06^{\prime} \mathrm{E}$ & 12.ii.2003 & $2 \mathrm{C}$ \\
\hline & 6 & Fulertal, Bhuban hill forest & $24^{\circ} 47^{\prime} \mathrm{N}-93^{\circ} 01^{\prime} \mathrm{E}$ & 14.viii.2002 & $1 \mathrm{~L}$ \\
\hline & 7 & Kumacherra, hill forest & $24^{0} 56^{\prime} \mathrm{N}-93^{\circ} 06^{\prime} \mathrm{E}$ & 30.vi.2004 & $1 \mathrm{~L}$ \\
\hline & 8 & Chailtacherra Basti, hill forest & $24^{\circ} 54^{\prime} \mathrm{N}-93^{\circ} 03^{\prime} \mathrm{E}$ & 29.vii.2004 & $1 \mathrm{C}$ \\
\hline & & \multicolumn{4}{|c|}{ Hailakandi District (Town $24^{\circ} 40^{\prime} \mathrm{N}-92^{\circ} 33^{\prime} \mathrm{E}$ ) } \\
\hline & 9 & Villaipur, forest village & $24^{0} 24^{\prime} \mathrm{N}-92^{\circ} 33^{\prime} \mathrm{E}$ & 13.iii.2003 & $1 \mathrm{C}$ \\
\hline & & \multicolumn{4}{|c|}{ Karimganj District (Town $24^{\circ} 51^{\prime} \mathrm{N}-92^{\circ} 22^{\prime} \mathrm{E}$ ) } \\
\hline & 10 & Sabri-Isabeel, forest village & $24^{\circ} 24^{\prime} \mathrm{N}-92^{\circ} 19^{\prime} \mathrm{E}$ & 04.vi.2003 & $1 C$ \\
\hline & 11 & Jherjheri, hill forest & $24^{0} 22^{\prime} \mathrm{N}-92^{\circ} 17^{\prime} \mathrm{E}$ & 06.xi.2003 & $1 C$ \\
\hline & 12 & Magura Basti, hill forest & $24^{\circ} 20^{\prime} \mathrm{N}-92^{\circ} 15^{\prime} \mathrm{E}$ & 05.vi.2003 & $1 C$ \\
\hline
\end{tabular}

Abbreviations: $\mathrm{L}=$ live specimens; $\mathrm{C}=$ Carapace; $(\# \mathrm{~L}$ or \#C) = (\# signifies number of live specimens or carapaces record) along with date of documentation; GPS Location available for sites.* Dialect of Bengali spoken in Barak Valley and the neighboring Sylhet District of Bangladesh.

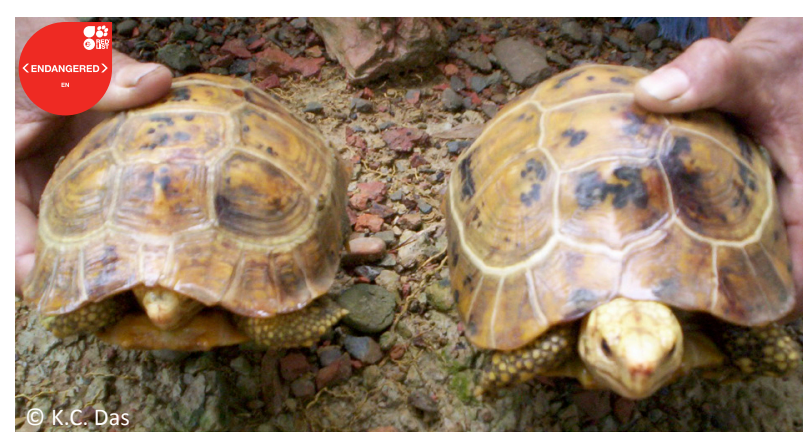

Image 1. Indotestudo elongata, Lailapur hill forest, Cachar District of Assam

according to IUCN Red List (ATTWG 2000). M. emys is the largest tortoise in Indo-malaya and the fourth largest in the world. It is the largest land tortoise of Asia. This species is also commonly called the Brown-hill Tortoise, Asian Giant Tortoise, Asian Tortoise, Black Giant Tortoise, Burmese Brown Tortoise, Burmese Mountain Tortoise, Six-legged Tortoise and Eastern Hill Tortoise. The

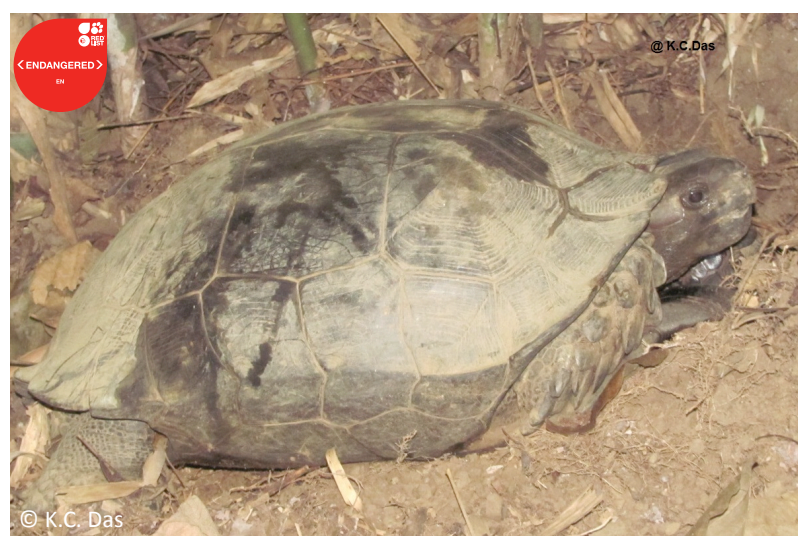

Image 2. Manouria emys phayrei, Lailapur hill forest, Cachar District of Assam

synonyms of $M$. emys are Geochelone emys (Schlegel \& Müller, 1840), Testudo emys (Schlegel \& Müller, 1840), T. phayrei (Blyth, 1853), M. fusca (Gray, 1854) and T. nutapundi (Reimann \& Nutaphand, 1979). As described 
in Table 1 the interesting linguistic vernacular name of this species varies from place to place and community to community.

Initial description of the genus Testudo was made by Linnaeus (1758) but the tortoise genus Geochelone (= earth turtle) was explained by Fitzinger (1835) and five years later, Schlegel \& Muller (1840) described $T$. emys from "Sumatra" (Indonesia). After then, Schlegel \& Muller (1844) referred to $G$. emys as the largest of the Asiatic Tortoise species of the genus Geochelone and afterwards this species emys (= tortoise), was listed under the subgenus Manouria (= rare, domed one) described by Gray (1852) as M. emys. Later on, a subspecies of this taxon was described by Blyth (1853) as $M$. emys phayrei. Two subspecies under $M$. emys are recognized: $M$. e. emys (Burmese Brown Mountain Tortoise) and M. e. phayrei (Burmese Black Mountain Tortoise). In general, the carapace is flattened on top, but broad, low and slightly wider in the posterior. The key difference between the two subspecies is found in the pectoral scutes. In M. e. phayrei the pectoral scutes normally meet at or near the midline (Ernst \& Barbour 1989; Cox et al. 1998), while they are widely separated in M. e. emys. Manouria emys emys has a more southerly range in southern Thailand, Malaysia, Sumatra, Borneo and some of the Indonesian Islands. This is also reported from Australia, China, Cambodia, Lao PDR and Vietnam (Gunther 1864; Gray 1870; Bourret 1941; Das 1991; Jenkins 1995). M. e. phayrei, the northern subspecies, ranges from central and northern Thailand, Myanmar and Bangladesh to India (Pritchard 1979; Obst 1983; Das 1985; Tikader \& Sharma 1985; Ernst \& Barbour 1989; Das 1991; Iverson 1992; Cox et al. 1998; Liat \& Das 1999; Iverson et al. 2001). In addition to a more northern range, it is larger $(60 \mathrm{~cm}$ carapace length), has larger clutches (51 eggs), and is generally darker, with a dark brown, olive or black domed carapace (Schaffer \& Morgan 2002).

In the subcontinent, it is recorded in the northeastern Indian states of Nagaland, Assam and Meghalaya (Smith 1931; Das 1990, 1991, 1996). However, Kundu et al. (2013a) recently reported the occurrence of different morphs of M. emys, Asian Forest Tortoise in northeastern India and revealed the new intergraded taxa within the two previously named species in the high altitude of Mizoram (23.47"41-23.4"23N \& 92.4"00-92.4"05E) State. Previous historical records of this species were from Lumajooting in the Naga Hills, presently in the state of Nagaland (Anderson 1872; Smith, 1931), and near Maibong, Langting-Mupa Reserve Forest and some other localities in the North Cachar Hills District of Assam (Anderson 1871, 1872). Barring one locality record of this species from Nongkhyllem Reserve Forest, East Khasi Hills, Meghalaya by Das (1990), no reliable record of this tortoise is available in other parts of India after Smith (1931). It was later reported from different areas of Nagaland, many localities in Assam including Kaliyani Reserve Forest of Karbi Anglong $\left(26^{\circ} 25^{\prime} \mathrm{N}\right.$ \& $93^{\circ} 35^{\prime} \mathrm{E}$ ), Barail Range of N.C. Hills (presently called Dima Hasao District), Innerline Reserve Forest of Cachar and Hailakandi and Nongkhyllem Wildlife Sanctuary of Ri-Bhoi and Balpakram National Park of South Garo Hills districts of Meghalaya (Choudhury 1996a,b). Earlier records from Mizoram were from Phura and Sangau in Saiha District (Choudhury 2001) and Dampa and Ngengpui sanctuaries (Pawar \& Choudhury 2000), all in western and southern Mizoram. Choudhury (2004) reported its occurrence in Lamzawl Village of Mizoram $(1000 \mathrm{~m})$ and it was reportedly obtained from the top of

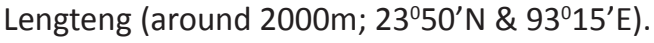

The present study reports its occurrence in five sites in Cachar District of Barak Valley region (Table 1). The species though largely herbivorous also consumes insects and frogs and is predominantly terrestrial in nature, inhabiting the hill forests of this valley. The size (straight carapace length $\mathrm{SCL}$ ) and weight of the specimens ranged from $42-55 \mathrm{~cm}$ and $10.5-20.75 \mathrm{~kg}$, respectively. The eggs of $M$. e. phayrei are round in shape, and large (diameter $4.59 \mathrm{~cm}$; weight $54.25 \mathrm{~g}$ ). A clutch size of about 60 was found during this study. Das (1995b) reported that $M$. e. emys is smaller (SCL up to $50 \mathrm{~cm}$, weight up to $20 \mathrm{~kg}$ ) than M. e. phayrei (SCL up to $60 \mathrm{~cm}$, weight up to $37 \mathrm{~kg}$ ). One of the $M$. e. phayrei specimens recorded in the present study was $55 \mathrm{~cm}$ long, indicating that it is perhaps one of the largest individuals recorded from this area. The specimens recorded by Pawar \& Choudhury (2000) were around $35 \mathrm{~cm}$ long. Food habits were also observed. The species is a voracious eater of a variety of animal food like dry fish, frogs, insects, etc. and plant foods like arum (stem, leaf and root), banana, cabbage, bamboo shoot etc.

\section{Indotestudo elongata}

The species, I. elongata (Blyth, 1853), is protected under Schedule-IV of Indian Wildlife (Protection) Act 1972 and categorized as "Endangered" according to IUCN Red List (Groombridge \& Wright 1982). This species is known as Elongated Tortoise, Pineapple Tortoise, Red-nosed Tortoise, Yellow-headed Tortoise and Yellow Tortoise. The synonyms of this species are G. elongata (Blyth, 1853), T. elongata (Blyth, 1853), and T. parallellus (Annandale, 1913). Although Blyth (1853) 
described T. elongata from "Arakan" (= Rakhine Yoma, a mountain range along coordinates ca. $18-21^{\circ} \mathrm{N} \& 93-$ $95^{\circ} \mathrm{E}$ ) in western Myanmar (Burma) apparently based on the collection of the ZSI in Calcutta (Das et al. 1998), Lindholm (1929) first recognized the distinctiveness of T. elongata and designated it as the type species of his new subgenus Indotestudo under the genus Testudo. Williams (1952) supported the creation of the subgenus Indotestudo under Testudo, and included elongata therein. Williams (p.220 in Loveridge \& Williams 1957) split the all-inclusive tortoise genus Testudo, placing elongata in the subgenus Indotestudo of the genus Geochelone, an arrangement followed by Auffenberg (1974). Bour (1980) subsequently elevated Indotestudo to full generic rank, a position supported by the cladistic analyses of Crumly (1982, 1984), and adopted by all subsequent authors. Pritchard (2000) reopened the controversy by examining the morphology of all three species of Indotestudo. However, Iverson et al. (2001) have hypothesized a phylogenetic relationship among the populations of Indotestudo. Kundu et al. (2013b) have revisited the taxonomic rank of Indian tortoise with DNA barcoding perspectives and depict that the molecular identification of $I$. elongata and an allopatric population of $I$. forstenii in northeastern India correspond correctly with existing morphological key support. Thus, the interesting local vernacular name of this species is also listed (Table 1) for additional traditional taxonomic support.

The shell of this species is considerably depressed, more than twice as long as it is deep, with flat vertebral region; anterior and posterior margins slightly reverted, strongly serrated in young, feebly in old specimens. Carapace and plastron are greenish-yellow, each shield with an irregular black spot or blotch, which may occupy its greater portion, or may be much broken up or indistinct (Boulenger 1890). Typically, I. elongata is around $30 \mathrm{~cm}$ in length and $3.5 \mathrm{~kg}$ as adult. Females tend to be wider than males and more rounded. Males also have a tail that is much larger than that of the female. The males have a concave plastron while the plastron of the female is flat. Additionally, the female's posterior claws are markedly longer and more curved than those of the male. It is believed that this is to facilitate nest building.

The elongated tortoise is distributed widely in North, Northeastern and Southern Bangladesh (Rashid \& Khan 2000), Nepal, Indo-China and Indo-Malaya, southeast to Pennang in Malaysia (Smith 1931), Southeast Asia, the Indian subcontinent is the northwestern limit of this tortoise (Das 1986, 2002). Essentially favoring the Sal forest, its range extends from Corbett National Park in Uttar Pradesh (Ross \& Crumly 1982; Frazier 1992). This species is also reported to be present in Phandowala near Dehra Dun (Frazier 1992), Siggudi forest near Kotdwara in the corridor connecting Rajaji and Corbett National Parks (Whitaker 1979; Bhupathy et al. 1994). It has also been reported from Simlipal Tiger Reserve in Odisha, Saranda Reserve Forest, Chaibassa in Bihar and Chhotanagpur in Jharkhand, Jalpaiguri sal forest and Buxa Tiger Reserve in West Bengal, Garo Hills in Meghalaya (Frazier 1992). It is found in the Dampa Tiger Reserve and Ngengpui Wildlife Sanctuary in Mizoram (Das 1991; Pawar \& Choudhury 2000), and Chakrashilla Wildlife Sanctuary in Dhubri District in Assam (Dutta 1997). In the present study, live specimens and caraplaces of this species were found in 12 sites in Cachar, Karimganj and Hailakandi districts of Barak Valley, Assam (Table 1). This species is predominantly terrestrial in nature and found in hill forests of this Valley. The size $(\mathrm{SCL})$ and weight of the specimens ranged from $18-49 \mathrm{~cm}$ and $0.18-2.5 \mathrm{~kg}$, respectively. It was also observed to be a voracious eater of a variety of animal food like dry fish, goat liver, snail, earthworm, frog, prawn, crabs, small fish, etc. and plant food like arum rhizome, fungus, mushroom, potato, tomato, radish, carrot, beetroot, cabbage, pumpkin, ash-gourd, bamboo shoot, Artocarpus chaplasha and jackfruit ( $A$. heterophyllus) seeds, Dioscorea roots etc.

This species is well represented in the Mizoram Zoo, collected from nearby areas (Pawar \& Choudhury 2000; Kundu et al. 2013b). It is highly likely that these species commonly occur in the hill forests inside Mizoram, as reported by the Dimasa and Mizo turtle hunters who make annual forays. However, the carapace records should be treated as possible sites where these turtles may be found and not as definitive site records as has also been pointed out by Frazier \& Das (1994). The villagers in this area hang turtle and tortoise shells in their cow sheds and homes as they ascribe some magico-religious properties to them (Gupta 2002; Das \& Gupta 2004). These tortoise species are utilized as food, traditional medicine and pets by a number of non-tribal (Hindu Bengali) and tribal communities (Mizo, Choroi, Hmar, Halam, Reang, Dimasa, Chakma, Pnar) of northeastern India. Tortoise shell and meat is used by different tribes for different purposes on the basis of their traditional practices, cultures and beliefs (Das et al. 2012).

Thus the present study indicates that the Barak Valley region of southern Assam still has a rich repository of turtle (Das \& Gupta 2011) and tortoise species. Both aquatic as well as forest-dwelling species are well-represented in this area and are encountered 
in a variety of habitats. The study also points out the urgent need for ex situ conservation of these species because of severe threats like shifting cultivation, illegal hunting or trade etc. and therefore to include certain rare species, viz., I. elongata and $M$. emys in the Schedule I of the Indian Wildlife (Protection) Act, 1972 instead of their present inclusion in the Schedule IV of the same act. This contention is vindicated by the inclusion of these two species by the IUCN in the highly threatened 'Endangered' category. The inclusion of the aforesaid species in the Schedule I of the Indian Wildlife (Protection) Act is expected to improve the conservation status of these species of chelonians.

\section{REFERENCES}

Ahmed, M.F., A. Das \& S.K. Dutta (2009). Amphibians and Reptiles of northeast India - A Photographic Guide. Aaranyak, Guwahati, India, xiv+168pp.

Anderson, J. (1871). A list of the reptilian accession to the Indian Museum, Calcutta from 1865 to 1870 , with a description of some new species. Journal of the Asiatic Society of Bengal 40(2): 12-39.

Anderson, J. (1872). On Manouria and Scapia, two genera of land tortoises. Proceedings Zoological Society London 26: 132-144.

Asian Turtle Trade Working Group (2000). Manouria emys. The IUCN Red List of Threatened Species. Version 2014.3. <http://www. iucnredlist.org>. Accessed on 14 March 2015.

Auffenberg, W. (1974). Checklist of fossil land tortoises (Testudinidae). Bulletin of Florida State Museum (Biological Science) 18(3): 121251.

Bhupathy, S., C.S. Silori \& S.F.W. Sunderraj (1994). Additional locality records for two Indian tortoise species. Journal of the Bombay Natural History Society 91(1): 149-150.

Blyth, E. (1853). Notices and descriptions of various reptiles, new or little known. Journal of Asiatic Society of Bengal 22(7): 639-655.

Boulenger, G.A. (1890). Fauna of British India, Including Ceylon and Burma. Reptilia and Batrachia. Taylor \& Francis, London, xviii+541pp.

Bour, R. (1980). Essai sur la taxinomie des Testudinidae actuels (Reptilia, Chelonii), Bulletin du Museum [national] d'histoire naturelle. Paris 2(2): 541-546.

Bourret, R. (1941). Les Tortues de l'Indochine. Inst. Oceanography. De Lindochine, 235pp.

Choudhury, A. (1996a). New localities for Brown Hill Tortoise Manouria emys (Schlegel and Muller) from Karbi Anglong, Assam. Journal of the Bombay Natural History Society 93(3): 590.

Choudhury, A. (1996b). Taxonomy of the brown hill turtle Manouria emys (Schlegel and Muller) and its distribution in Indian Subcontinent. Cheetal 35(3-4): 36-39.

Choudhury, A. (2001). Some chelonian records from Mizoram. Journal of the Bombay Natural History Society 98(2): 184-190.

Choudhury, A. (2004). Further chelonian records from Mizoram in northeast India. Journal of the Bombay Natural History Society 101(1): 165-166.

Cox, M.J., P.P. van Dijk, J. Nabhitabhata \& K. Thirakhupt (1998). A Photographic Guide to Snakes and Other Reptiles of Peninsular Malaysia. Singapore and Thailand. Ralph Curtis Books, Sanibel Island, $144 \mathrm{pp}$

Crumly, C.R. (1982). A cladistic analysis of Geochelone using crania osteology. Journal of Herpetology 16(3): 215-234.

Crumly, C.R. (1984). A hypothesis for the relationship of land tortoise genera (family Testudinidae). Studia Geologica Salmanticensia, Vol. Especial 1. Studia Palaeochelonologica 1: 115-124.
Das, I. (1985). Indian Turtles: A Field Guide. WWF-India (eastern region), Eureka Publicity Service, Calcutta, 119pp.

Das, I. (1986). The diversity and utilization of land tortoises in tropical Asia. Tigerpaper 13(3): 18-21.

Das, I. (1990). Distributional records for the chelonians from North Eastern India. Journal of the Bombay Natural History Society 87: 91-97.

Das, I. (1991). Colour Guide to The Turtles and Tortoises of The Indian Subcontinent. R and A Publishing Limited, Portishead, UK, vi+133pp.

Das, I. (1995a). Turtles and Tortoises of India. WWF India and Oxford University Press, Bombay, Delhi, Calcutta and Madras, xi+174pp.

Das, I. (1995b). An illustrated key to the turtles of insular South-east Asia. Hamadryad 20: 27-32. Same title reprinted In: Proceedings of International Congress of Chelonian Conservation. SOPTOM (Ed.), Editions Soptom, Gonfaron, France, 77-80pp.

Das, I. (1996). Biogeography of the Reptiles of South Asia. Krieger Publishing Company, Malabar, Florida, 87pp.

Das, I. (2002). A Photographic Guide to Snakes and Other Reptiles of India. New Holland Publishers (UK) Ltd. Garfield House, Edgware Road, London W2 2EA,UK, 144pp.

Das, I. \& H.V. Andrews (1997). Checklist of Indian Reptiles. In: B.C.P.P. C.A.M.P., India. Reptiles. 19-23 May 1997. Zoo Outreach Organization, 79 Bharati Colony, Peelamadu, Coimbatore-641004, India, 1-11pp.

Das, I., B. Dattagupta \& N.C. Gayen (1998). History and catalogue of reptile types of the Zoological Survey of India. Journal of South Asian Natural History 3(2): 121-172.

Das, K.C. (2008). Diversity and Ecology of Chelonians and Their Conservation in Barak Valley, Assam, North East India. PhD Thesis. Department of Ecology and Environmental Science, Assam University, Silchar, $213 p p$.

Das, K.C. \& A. Gupta (2004). Turtle market survey in Silchar, Assam. Northeast India. Turtle and Tortoise Newsletter 8: 17-18.

Das, K.C. \& A. Gupta (2011). Site records of softshell turtles (Chelonia: Trionychidae) from Barak Valley, Assam, northeastern India. Journal of Threatened Taxa 3(4): 1722-1726; http://dx.doi.org/10.11609/ JoTT.02487.1722-6

Das, K.C., S. Kundu, S.K. Ghosh \& A. Gupta (2012) Traditional knowledge on zootherapeutic uses of turtle is an issue for international conservation, pp. 81-89. In: Singh, K.B. \& K. Lalchhandama (eds.). Proceedings of the National Seminar on Recent Advances in Natural Products Research.

Dutta, S. (1997). Fresh water turtles and land tortoises of Dhubri District, Zoos' Print XII(6): 1-4.

Ernst, C.H. \& R.W. Barbour (1989). Turtles of The World. Smithsonian Institution Press, Washington, D.C, 313pp.

Fitzinger, L.J. (1835). Entwurf einer systematischen Anordnung der Schildkroten nach den Grundsatzen der naturlichen Methode. Ann. Mus. Naturgesch. Wien 1: 105-128.

Frazier, J.G. (1992). The land tortoises in Nepal: a review. Journal of the Bombay Natural History Society 89(1): 45-54.

Frazier, J.G. \& I. Das (1994). Some notable records of testudines from the Indian and Burmese subregions. Hamadryad 19: 47-66.

Gunther, A. (1864). The Reptiles of British India. Harwicke, London, 452pp.

Gupta, A. (2002). The beleagured chelonians of northeast India. Turtle and Tortoise Newsletter 6: 16-17.

Gray, J.E. (1854). Description of new genus and some new species of tortoises. Proceedings of the Zoological Society of London, 133$135 p p$.

Gray, J.E. (1870). Supplement to the catalog of shield reptiles in the Collection of the British Museum, Part I, Testudinata (Tortoises): with figures of the skulls of 36 genera, London, 120pp.

Groombridge, B. \& L. Wright (1982). The IUCN Amphibia-Reptilia Red Data Book. Part I Testudines, Crocodilia, Rhyncocephalia. IUCN, Gland, (4)+xiii+426pp.

Iverson, J.B. (1992). A Revised Checklist With Distribution Maps of The Turtles of The World. Privately printed, Richmond (Indiana), xiii+363pp. 
Iverson, J.B., A.R. Kiester, L.E. Hughes, A.J. Kimerling \& K. Sahr (2001). Turtles of the World. http:// bufo.geo.orst.edu/turtle/index.html.

Jenkins, M.D. (1995). Tortoises and Freshwater Turtles: The Trade in Southeast Asia. Cambridge, UK Traffic International, 48pp.

Kundu, S., K.C. Das, H.T. Lalremsanga, A. Gupta \& S.K. Ghosh (2013a) A new report for all representatives of Asian Forest Tortoise has their footmarks in northeast India, pp. 241-245. In: Singh, K.K., K.C. Das \& H. Lalruatsanga (eds.). Bioresources and Traditional Knowledge of Northeast India. MIPOGRASS, India.

Kundu, S., K.C. Das \& S.K. Ghosh (2013b). Taxonomic rank of Indian tortoise: revisit with DNA barcoding perspective. DNA Barcodes, Versita 1: 39-45; http://dx.doi.org/10.2478/dna-2013-0003

Linnaeus, C. (1758). Systema Naturae, per Regna Tria Naturae, secundum Classes, Ordines, Genera, Species, cum Characteribus, Differentiis, Synonymis, Locis. Tomus I. Editio Decima, Reformata [10 ${ }^{\text {th }}$ Ed.] Holmiae[Stockholm]: Laurentii Salvii, 824pp.

Liat, L.B. \& I. Das (1999). Turtles of Borneo and Peninsular Malaysia. Natural History Publications, Kota Kinabalu, viii $+151 \mathrm{pp}$.

Lindholm, W.A. (1929). Revidiertes verzeichnis der gattung de rezenten Schildkröten nebst notizen zur nomenklatur einiger Arten. Zool. Anz. 81: 275-295.

Loveridge, A. \& E.E. Williams (1957). Revision of the African tortoises and turtles of the suborder Cryptodira. Bull. Mus. Comp. Zool. Harvard 115(6): 163-557.

Obst, F.J. (1983). Betrage zur Kenntnis der LandschildkrotenGattung Manouria Gray, 1852. (Reptilia, Testudines, Testudinidae). Zoologische Abhandlungen Staatliches Museum fur Tierkunde in Dresden 38: 247-256.

Pawar, S.S. \& B.C. Choudhury (2000). An inventory of chelonians from Mizoram, north-east India: new records and some observations of threats. Hamadryad 25(2): 144-158.

Pritchard, P.C.H. (1979). Encyclopedia of Turtles. T.F.H Publications, Inc., Neptune, New Jersey, 895pp.

Pritchard, P.C.H. (2000). Indotestudo travancorica...A valid species of tortoise? Reptile \& Amphibian Hobbyist 5(6): 18-28.
Rashid, S.M.A. \& S.M.M.H. Khan (2000). Trade and conservation status of freshwater turtles and tortoises in Bangladesh. In: van Dijk, P.P., B.L. Stuart \& A.G.J. Rhodin (eds.). Asian Turtle Trade: Proceedings of Workshop on Conservation and Trade of Freshwater Turtles and Tortoises in Asia. 1-4 December 1999. Phnom Penh, Cambodia, Chelonian Research Monographs 2: 77-85.

Reimann, M. \& W. Nutaphand (1979). Reimann, M. 1979. [Testudo nutapundi], pp. 193-195. In: Nutaphand, W. (ed.). The Turtles of Thailand. Bangkok: Siamfarm Zoological Garden.

Ross, C.A. \& C.R. Crumly (1982). A range extension of Geochelone elongata. Journal of the Bombay Natural History Society 79(2): 429-430.

Schaffer, C. \& V. Morgan (2002). Behavioral observations of captive juvenile Manouria emys phayrei with notes on degrees of intergradation with Manouria emys emys. Turtle and Tortoise Newsletter 5: 2-6.

Schlegel, H. \& S. Müller (1844). Over de Schildpadden van den Indischen Archipel, pp. 29-36. In: Temminck, V. (1839-1847) Verhandelingen over de natuurlijke geschiedenis der Nederlandsche overzeesche bezittingen, door de leden der Natuurkundige Commisie in OostIndie en andere schrijvers. Leijden folio. Afd. 1 Zoologie in 12 afleveringen, met 45 gekl. pl. - Vitg. door C.J. Temminck, Leiden, Leuchtmans u. Hoeck in comm.

Smith, M.A. (1931). The Fauna of British India, Ceylon and Burma: Amphibia and Reptilia. Vol. I - Loricata, Testudines. Taylor and Francis Ltd., London, 185pp.

Tikader, B.K. \& R.C. Sharma (1985). Handbook: Indian Testudines. Zoological Survey of India, Calcutta, 156pp.

Whitaker, R. (1979). The crocodilians of Corbett National Park. Indian Forester 2: 38-40.

Williams, E.E. (1952). A new fossil tortoise from Mona Island, West Indies, and a tentative arrangement of the tortoises of the world. Bulletin of the American Museum of Natural History 99: 541-560.

Uetz, P. \& J. Hošek (eds.) (2014). The Reptile Database, http://www. reptile-database.org. accessed November 14, 2014. 